\title{
Review Article \\ PADDY STRAW MUSHROOM (Volvariella spp.): A NATURAL SCAVENGERS WHO HELP IN MALNUTRITION AND
ENVIRONMENT PROTECTION
}

SINGH KAUSHIK, DEY IPSITA AND SHRVAN KUMAR

RGSC, Institute of Agricultural Sciences, Banaras Hindu University, Barkachha, Mirzapur, 231001, Uttar Pradesh, India

*Corresponding Author: Email-shrvank@gmail.com

Received: April 28, 2018; Revised: May 07, 2018; Accepted: May 15, 2018; Published: May 30, 2018

\begin{abstract}
Rice, Oryza sativa L. $(2 n=24=A A)$ is the principal food crop to people in India. India occupies a pride place in rice production among the food crops cultivated in the world. In India, rice is being grown in $45.10 \mathrm{Mha}$ area with production of $111.01 \mathrm{MMT}$ and productivity of $3.52 \mathrm{MT} / \mathrm{ha}$, respectively in 2017-18. This rice is produce 1.5 times paddy straw in nature. It is containing hemicellulose (26 to $35 \%)$, cellulose (38 to $41 \%)$, lignin (12-16\%), water soluble polysaccharides ( $8 \%$ ), $15-20 \%$ of ash and $9-14 \%$ of silica, which is recalcitrant for degradation. In flooded rice field is a major substrate for the production of methane that is responsible for a greenhouse gas effect. Wetland rice fields annually release about 60 to $100 \mathrm{MMT}$ of $\mathrm{CH}_{4}$ and thus contribute substantially to the global warming of the atmosphere. Methane emission from rice fields starts after the flooding of the fields and stops when the fields are drained for harvest. Rates of $\mathrm{CH}_{4}$ production were higher in incubations with straw from the stems >leaf blades> leaf sheaths > unamended soil. In many countries, massive amounts of the post-harvest rice residues are eliminated through burning, which represents a threat to public health and poses an environmental pollution problem. Alternatives to burning include potential feedstock to produce biofuels, bio-fertilizers, animal feed, bio-based industry chemicals, cheap substrate for fermentation of enzymes, biogases, mushroom cultivation and bio-compost. As early as in 1822, paddy straw mushroom was first cultivated in China. In India this mushroom was first cultivated in early 1940's. In India, 19 edible species of Volvariella have been documented but most important are three of them only viz; V. esculenta (Mass) Sing., V. diplasia (Berk and Br.) Sing. and V. volvacea (Bull. ex Fr.) Sing. Volvariella volvacea are great source of Carbohydrate $(54.80 \%)>$ Protein $(37.50 \%)>$ Fibre $(5.50 \%)>$ Fat $(2.60 \%)>$ Ash $(1.10 \%)$ and Energy $k$ cal $(305)$ in $100 \mathrm{~g}$ dry weight. They have ergo-sterol that acts as a precursor for Vitamin D synthesis in human body. Ergo-sterol is converted in to vitamin $\mathrm{D}_{2}$ when exposed to UV- radiation or sunlight also. Bed cost is about 60-70 rupees and Yield of bed is appx. 1.0-1.5 kg i.e., Price of mushroom Rs. 200/- return as per market value. So, farmers can get net profit of 130/- or at least Rs. 100/profit per bed within 15 days. So, it can be used as a weapon against malnutrition and environment protection also.
\end{abstract}

Keywords- Oryza sativa, Ergo-sterol, Volvariella volvacea, V. esculenta and V. diplasia

Citation: Singh Kaushik, et al., (2018) Paddy Straw Mushroom (Volvariella spp.): A Natural Scavengers who help in Malnutrition and Environment Protection. International Journal of Microbiology Research, ISSN: 0975-5276 \& E-ISSN: 0975-9174, Volume 10, Issue 5, pp.-1183-1185.

Copyright: Copyright@2018 Singh Kaushik, et al., This is an open-access article distributed under the terms of the Creative Commons Attribution License, which permits unrestricted use, distribution and reproduction in any medium, provided the original author and source are credited.

Academic Editor / Reviewer:

\section{Introduction}

Worldwide more than 3000 mushrooms have been identified as edible, of which 200 types are reported to have been produced under controlled conditions. India is home to more than 300 varieties of mushrooms found in the wild. The global mushroom production (in tonnes) ranks as per FAO Statistics-2016 was estimated i.e., China (7797929)>USA (260140)>Netherlands (300000) >Polands (260140) and India (29992) [1]. However, per capita consumption of mushrooms in India is less than 50 gases against over a $\mathrm{kg}$ in various countries. Volvariella mushrooms account for $16 \%$ of total production of cultivated mushrooms in the world. Paddy straw mushroom (V. volvacea) is an edible mushroom of the tropics and subtropics [2]. It was first cultivated in China as early as in 1822. The straw mushroom was familiarized into Philippines, Malaysia, and other South-East Asian countries by overseas Chinese around 1932-35 [3]. In India this mushroom was first cultivated was the first to be cultivated in India as early as 1943 by Thomas and his associates at Coimbatore. In India, nineteen edible species of Volvariella have been reported nevertheless most cultivation methods have been formulated only for three species namely, V. esculenta (Mass) Sing., V. diplasia (Berk and Br.) Sing. and V. volvacea (Bull. ex Fr.) Sing.
Pre-disposing factors for the growth of this mushroom are $35^{\circ} \mathrm{C}$ temperature and $57-60 \%$ relative humidity, respectively $[4,5]$. Proximate composition of fresh paddy straw mushroom (100g) i.e., Moisture $90.40 \mathrm{~g}>$ Protein $3.90 \mathrm{~g}>$ Crude fibers $1.87 \mathrm{~g}>$ Ash $1.10 \mathrm{~g}>$ Fat $0.25 \mathrm{~g}>$ Ascorbic acid $18.00(\mathrm{mg})>$ Calcium $5.60(\mathrm{mg})>$ Niacin 2.40 $(\mathrm{mg})>$ |ron $1.70(\mathrm{mg})>$ Riboflavin $0.61(\mathrm{mg})>$ Potassium $0.32(\mathrm{mg})>$ Thiamine 0.14 $(\mathrm{mg})>$ Phosphorus $0.10(\mathrm{mg})$ and Amino acid contents of paddy straw mushroom (mg/100g protein) i.e., Valine 6.8> Isoleucine 5.5> Phenyl alanine 4.9> Lysine 4.3> Threonine 4.2> Arginine 4.1> Leucine 3.5> Histidine 2.1> Tryptophane 1.1> Methionine $0.9[5,6]$

\section{Methodology}

Mushroom Spawn- Mushroom spawn (seed) required 250 -350 g per mushroom bed. Nutrition- Bengal gram, lentil, horse gram, red gram, black gram or green gram and wheat bran and paddy husk powder are used for nutrition supply. Powder obtained from Bengal gram with its seed coat gives more yield form powder of bengalgram with seed coat [7]. 


\section{Material requirement}

Straw bundles-15-20 bundles of straw (per bundle $1.5 \mathrm{~kg}$ ), Spawn (Seed)-One bottle or $250 \mathrm{~g}$, Nutrition- $250 \mathrm{~g}$ of Bengal or red gram, Bed Size- $2 \mathrm{ft} \times 2 \mathrm{ft}$, Space$3 \mathrm{ft} \times 3 \mathrm{ft}(7-10 \mathrm{sq} \mathrm{ft} / \mathrm{bed})$.

\section{Cultivation Method}

1) Remove leaves of the straw bundle and cut to $2 f t$ size with a straw cutter. The required number of straw bundles are soaked in a tank of sterilizer solution \{formalin $(100 \mathrm{ml})+$ bavistin $(100 \mathrm{~g})+\mathrm{H} 20(100 \mathrm{~L})\}$ for 12 to 16 hours.

2) Remove the straw bundles from water and keep in standing positions for 5 to 6 hours and only $75 \%$ moisture will remain in the straw bundles.

3) 2 to 3 weeks old spawn divided in to 4 equal parts and make into small pieces.

4) As nutrition, use $250 \mathrm{~g}$ of Dal powder grinded from whole grain of Bengal gram.

Else use paddy husk or rice bran to reduce the cost of cultivation.

5) Firstly, put a layer of straw of 6 inches that the top portion of straw are inside and bases are outer side. Put one part of the spawn pieces on the bed leaving 2 inches from outer side and at 3 inches distance. Powder of nutrition sprinkled over the spawn blocks and nearby area.

6) Put again second layer 6 inches height of straw over the first layer. Arrange the straw on the opposite direction of the first layer. Sprinkle another part of spawn at a distance of 3 to 4 inches as in the first layer. Also sprinkle the nutrition powder over it has done previously.

7) Put another 3rd layer of 6 inches of straw as like direction of 1 st layer and put rest 2 parts of spawn over the third layer and sprinkle 2 parts of nutrition powder too.

8) Final 4th layer of straw of 1 to 2 inches width, parallel to the 2 nd layer cover the third layer and press the layer at the top so that the mycelium can grow well. The spilled straw all around the bed cut it.

9) Ready bed cover with help of white polythene sheet. It may be removed for 30 minutes daily for aeration after 4-5 days bed preparation and only dried portion of straw bed is spray water.

10) For aeration purpose, the polythene cover may be removed after 10 to 11 days. 11) Harvesting: Best taste and flavour in cooking at budding stage therefore mushroom should be harvested at bud stage (dia. 2.5-3.5 cm and height 6.0-8.0 cm) 13-15 days of sowing.

\section{Profit Analysis}

Paddy straw mushroom has a production cycle of only 15 days i.e., this selfemployment, farmers can get their return within 15 days. Cost per bed is about 60 70 rupees (INR) and Yield from one bed is appx. $1 \mathrm{~kg}$ to $1.5 \mathrm{~kg}$ i.e., about Rs. 200/return as per market price of mushroom. So, farmers can get net profit of $130 /-$ or at least Rs. 100/- profit per bed within 15 days [8].

\section{Importance of Mushroom cultivation \\ - Mushroom as a Source of Protein and other Food Nutrient \\ - Unique Flavour and Exotic Taste \\ - Medicinal Properties \\ - Easy and Simple Production Procedure \\ - Labour Intensive Method of Cultivation \\ - Absence of Crop Competition \\ - $\quad$ Suitable Enterprise for Farm Ladies \\ - Utilization of Agro-Wastes in Mushroom Cultivation \\ - Export Potential}

Insect and Pests: The economically important insect and pests of paddy straw mushroom recorded in India and elsewhere are sciarids (Bradysia tritici, Lycoriella auripilla), Phorids (Megaselia agarici, Megaselia spp.) Spring tails (Lepidocyrtus spp., Seira iricolor) and mites (Tyrophagus putrescentiaem, T. Beriesei, Rhizoglyphus echinopus, Histiostoma heinemanni, Hypoaspis miles) and Several competitor moulds namely, Coprinus aratus, C. cinereus, C. lacopus, Psathyrella sp., Penicillium spp., Aspergillus spp., Rhizopus spp. Mucor spp., Trichoderma spp., Sclerotium spp. and Bacterial blotch (Pseudomonas tolaasii) have been reported from the substrate [9-16]. Combination of insecticide, fungicide and antibiotic (Malathion $0.025 \%$ + dithane Z-78 or benomyl $0.025 \%$ + tetracycline $0.025 \%$ ) are recommended for the management of pests and diseases $[17,18]$.

\section{Conclusion}

Currently, many countries, massive amounts of the post-harvest rice residues are eliminated through burning, which represents a threat to public health and poses an environmental pollution problem. Alternatives to burning include potential feedstock to mushroom cultivation. This mushroom cultivation helps to the youngster selfemployment also. After mushroom cultivation, west material can be used biocompost for agriculture field. There has nutrient binding, soil water holding capability and decrease soil erosion also. Mushrooms are miniature pharmaceutical factories, and of the thousands of mushroom species in nature, our ancestors and modern scientists have identified several dozen that have a unique combination of talents that improve our health.

Application of review: This review article helps in rice straw mushroom cultivation that provide knowledge of self-employment, nutritive food, bio-compost and environment protection also

\section{Review Category: Natural Scavengers}

\section{Abbreviations:}

I. Ag. Sc.- Institute of Agricultural Sciences

BHU- Banaras Hindu University

MMT- Million metric ton

UV- Ultra Violate

Acknowledgement / Funding: Author are thankful to Banaras Hindu University, Varanasi, 221005, Uttar Pradesh, India

\section{*Principle Investigator: Shrvan Kumar \\ University: Banaras Hindu University, Varanasi, 221005, Uttar Pradesh \\ Research project name or number: Nil}

\section{Author Contributions: All author equally contributed}

Author statement: All authors read, reviewed, agree and approved the final manuscript

\section{Conflict of Interest: None declared}

Ethical approval: This article does not contain any studies with human participants or animals performed by any of the authors.

\section{References}

[1] FAOSTAT (2016) http://www.fao.org/faostat/en/\#data Retrieved $2017-$ 04-28.

[2] Sharma V.P., Annepu S.K., Gautam Y., Singh M. and Kamal S. (2017) Mushroom Research, 26 (2), 111-120.

[3] Chang S.T. (1977) Econ Bot., 31, 374-376.

[4] Ahlawat O.P. and Kumar S. (2005) Traditional and modern cultivation technologies for the paddy straw mushroom (Volvariella spp.). In Frontiers in Mushroom Biotechnology (Rai RD, Upadhyay RC and Sharma SR, Eds.), National Research Centre for Mushroom, Solan (HP), India, 157-164.

[5] Ahlawat O.P., Kumar P., Rai R.D. and Tewari R.P. (2006) Indian J Micobiol., 46(1), 31-37.

[6] Ahlawat O.P. and Tewari R.P. (2007) Cultivation technology of paddy straw mushroom (Volvariella volvacea) 2007. National Research Centre for Mushroom-ICAR, Chambaghat, Solan -173213 (HP), 1-44.

[7] https://padmavatiproducts.in/cultivation-of-mshroom 
[8] http://www.eco-mushroom.com/ Retrieved 2017-04-22.

[9] Bahl N. and Chowdhary P.N. (1980) Curr. Sci., 50, 37

[10] Hepperly R. P. and Ramos-Dâvila E. (1986) J. Agric. Univ. P. R., 70(3), 219-221.

[11] Grewal P.S. and Grewal S.K. (1998) Phytopathol. Mediterranea, 27, 112-114.

[12] Raina P.K., Tikoo M.L. and Kalha C.S. (2003) Mushroom Res, 12(1), 39-42.

[13] Kumar S., Gautam Y. and Sharma S.R. (2004) Mushroom Res, 13(2), 46-52.

[14] Sharma S.R., Kumar S. and Sharma V.P., (2007) Diseases and Competitor Moulds of Mushrooms and their Management. National Research Centre for Mushroom-ICAR, Chambaghat, Solan -173213 (HP), 1-85.

[15] Ahlawat O.P., Singh R. and Kumar S. (2011) Indian J Microbiol., 51(2), 200-205.

[16] Gahukar R.T. (2014) International Journal of Vegetable Science, 20(1), 78-88.

[17] Kannaiyan S. and Prasad N.N. (1978) Indian Mush. Sci., 1, 287-293.

[18] Singh M., Vijay B., Kamal S. and Wakchaure G.C. (2011) Mushrooms Cultivation, Marketing and Consumption. Directorate of Mushroom Research-ICAR, Chambaghat, Solan -173213 (HP),1-278. 